\title{
Does Teaching Load Affect Faculty Size?
}

by

William E. Becker. William H. Greene, and John J. Siegfried

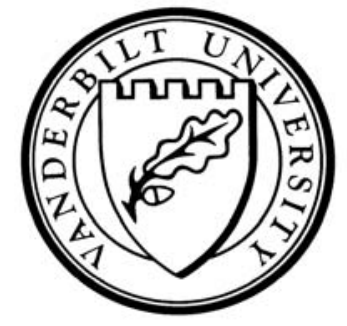

Working Paper No. 08-W17

September 2008

\section{DEPARTMENT OF ECONOMICS \\ VANDERBILT UNIVERSITY \\ NASHVILLE, TN 37235}

www.vanderbilt.edu/econ 


\title{
Does teaching load affect faculty size?
}

\author{
William E. Becker, William H. Greene and John J. Siegfried*
}

\begin{abstract}
Random effects estimates using panel data for 42 colleges and universities over 16 years reveal that the economics faculty size of universities offering a Ph.D. in economics is determined primarily by the long-run average number of $\mathrm{Ph} . \mathrm{D}$. degrees awarded annually; the number of full-time faculty increases at almost a one-for-one pace as the average number of Ph.D.s grows. Faculty size at Ph.D. granting universities is largely unresponsive to changes in the number of undergraduate economics degrees awarded at those institutions. In contrast, faculty size at colleges where a bachelor's is the highest degree awarded is responsive to the average number of economics degrees awarded annually, growing by about one for each additional eleven graduating economics majors.

*William Becker is Professor of Economics, Indiana University, Adjunct Professor of Commerce, University of South Australia, and Research Fellow, Institute for the Study of Labor (IZA, Germany). William Greene is Professor of Economics, Stern School of Business, New York University. John Siegfried is Professor of Economics, Vanderbilt University, Senior Research Fellow, University of Adelaide, South Australia, and Secretary-Treasurer of the American Economic Association. Their e-mail addresses are < beckerw@indiana.edu>, $<$ wgreene@stern.nyu.edu $>$ and $<$ john.siegfried@vanderbilt.edu $>$.
\end{abstract}

September 9, 2008: 1 


\section{Does teaching load affect faculty size?}

Most academic economists at one time or another have participated in department meetings in which the relationship between the size of the student body and size of the faculty has been discussed. Arguments are made that at least in the short run, the number of faculty members is not affected by the number of students. Nevertheless, department chairs invariably parade rising numbers of undergraduate majors before their dean when requesting additional faculty slots (while often remaining mute when the number of majors in their department declines). Some faculty are cynical about the likely administrative response, anticipating that deans are likely to allow class sizes to rise during periods of increasing demand, especially for short periods, because the expansion of tenured or tenure-track faculty is difficult to reverse if the number of majors subsequently should decline. In the extreme, of course, if there are no students there is no need for a faculty.

Within departments that offer both undergraduate and graduate degrees, there is also debate about which, if either, drives faculty size. For example, Isaac Ehrlich (2006), Department of Economics Chair, University of Buffalo, observed that in 2000 his department had sunk to 10 full-time tenured and tenure-track members, down from 18 in 1991. "Since the 1997 academic year, however, the department has experienced a multidimensional revival. Faculty size is back to 18 this fall ... We also have experienced a tremendous growth in the number of students we serve, primarily at the graduate level, which also serves as the engine of faculty growth."

The responsibilities of a typical economics department include a variety of tasks that extend beyond providing for the education of undergraduate majors and Ph.D. students: general education (principles of economics and seminars for first-year students), service courses for

September 9, 2008: 2 
other departments (e.g., money and banking for business majors), interdisciplinary teaching, occasionally a master's program, faculty research and publication, and faculty service (e.g., media relations, extension and other outreach activities, especially at public universities). Changes in the demand for any of these services can at least in theory create incentives for a supply response. The critical issue, however, comes back to the relationship between faculty size and students.

Here we examine whether undergraduate degrees (BA and BS) in economics or Ph.D. degrees $(\mathrm{PhD})$ in economics drive faculty size at those institutions that offer only a bachelor's degree and those that offer both bachelor's degrees and Ph.D.s. At bachelor's degree level institutions faculty size is primarily determined by a specific long-term expected number of students, with deviation from this long run mean having little effect on faculty size in departments of economics. At institutions awarding both the bachelor's degree and Ph.D., faculty size is predicted to increase with the long term target number of $\mathrm{Ph}$.D.s to be awarded per year and not deviations from this long term average.

\section{Data}

Our sample observations come mostly from data collected annually by the American Economic Association. The number of undergraduate economics degrees per institution per year is taken from the AEA's Universal Academic Questionnaire (UAQ), supplemented by e-mail requests to individual departments. These data form the basis for a report that has been published by one of us annually for many years in the Summer issue of the Journal of Economic Education (Siegfried, 2008). The numbers of Ph.D. degrees in economics awarded by departments are 
obtained from the Survey of Earned Doctorates, which is jointly sponsored by a half-dozen federal government agencies.

We have degree data for each year from 1990-91 through 2005-06 for every included institution, with one exception: data on Ph.D. degrees were not collected for 1998-99. We measure degrees rather than majors or number of enrolled Ph.D. students because undergraduate students declare their major at different points during their educational experience at different colleges and universities, and Ph.D. enrollments do not correlate well with either students doing coursework, students on campus, or completions. The sample period begins in 1990-91 because that is the year that was selected as a benchmark for a study of the precipitous decline in undergraduate economics majors that occurred in the mid-1990s. The period ends with 2005-06 because those were the latest data available when we began the present study. Fortunately 199091 through 2005-06 includes a complete cycle of undergraduate degrees, the aggregate numbers declining by over 30 percent of initial year values in the mid-1990s, and then more than fully recovering over the subsequent decade.

The number of full-time tenured or tenure-track faculty are also collected from the UAQ. We included in our sample each institution for which we also have undergraduate economics degree data and for which the number of years of missing faculty data is no more than three over the entire 16 year interval for each institution, with no two consecutive years missing for any institution. We interpolated missing data on the number of faculty from the reported information in the years prior and after a missing observation. In a few cases, the department provided a precise number from its records to replace a missing observation.

September 9, 2008: 4 
The result is a sample of 16 years of data for each of 18 colleges for which the bachelor's degree is the highest degree awarded in economics, and 24 universities for which a Ph.D. is the highest degree awarded in economics. The 18 colleges for which the bachelor's degree is the highest degree awarded all emphasize teaching. In terms of the objectives and constraints of the different types of institutions, we would expect the strongest response of faculty numbers to degrees to occur at such teaching oriented colleges, where class size is an important characteristic that distinguishes them from research universities. We would expect the weakest response of faculty to the number of undergraduate degrees at universities that offer a Ph.D. in economics because the missions those institutions embrace, possibly even emphasize, are graduate education and faculty research. Undergraduate education, and especially class size, is a less important concern at research universities.

Table 1 provides descriptive statistics on the 18 bachelor degree granting colleges and the 24 universities offering both bachelor and doctorate degrees in the 16 years from 1991 through 2006. Important to note, however, is that the number of Ph.D.s awarded in 1999 is not available from the Survey of Earned Doctorates or anywhere else. To sustain the balanced panels for the entire period, for 1999 we insert the mean of the 1998 and 2000 numbers of Ph.D.s awarded by each of the 24 universities. Not surprisingly, both the distribution of bachelor and Ph.D. degrees granted and number of faculty members are positively skewed. One bachelor degree granting institution awarded no degrees in 1995, which likely would have spelled the end of the department had it not soon thereafter restored a positive number of graduates. One Ph.D. granting private university awarded no Ph.D. degrees and only four bachelor's degrees in 1992 but these were aberrations compared to its long-run average of two and seven respective degrees per year. At the other extreme, in 2003 a maximum of $45 \mathrm{Ph}$.D. degrees (and 409 bachelor September 9, 2008: 5 
degrees) were awarded by one large state university that averaged $32 \mathrm{PhD}$. degrees (and 394 bachelor degrees) over the 1991 - 2006 period. The largest number of economics bachelor's degrees, 682, was awarded in 2003 by a public university, which awarded 9 Ph.D. degrees that year, and averaged 553 bachelor degrees and $6 \mathrm{Ph} . \mathrm{D}$. degrees over the entire period.

Private institutions $($ PRIVATE $=2$ ) are more prevalent than public institutions (PUBLIC $=1$ ) in the sample for both bachelor and Ph.D.-granting institutions, and this is especially so for the bachelor schools. Finally, a $0-1$ binary variable that indicates the absence or presence of a business degree program is included based on findings reported in the series of empirical studies appearing in the Fall 1996 issue of the Journal of Economic Education, Salemi (1996). For the undergraduate programs this dummy (Bschl) simply reflects whether there is a business program. For institutions with a Ph.D. program in economics, an MBA dummy variable was created to test whether the instructional servicing of MBAs and not just the presence of a business school drives faculty size.

\section{Basic Model and Estimates}

As a starting point, consider the least squares estimations of the models of faculty size for the panel data on the two classes of institutions in Table 1, assuming the faculty-size-generating process for bachelor's degree-granting undergraduate departments is:

$$
\begin{aligned}
& {\text { FACULTY } \text { size }_{i t}=\beta_{1}+\beta_{2} Y_{E A R_{t}}+\beta_{3} B A \& S_{i t}+\beta_{4} M E A N B A \& S_{i}+\beta_{5} P U B L I C_{i}} \\
& +\beta_{5} B s c h l+\varepsilon_{i t}
\end{aligned}
$$

September 9, 2008: 6 
where error term $\varepsilon_{i t}$ is iid across institutions and over time and $\mathrm{E}\left(\varepsilon_{i t}{ }^{2} \mid \mathrm{x}_{\mathrm{it}}\right)=\sigma^{2}$ for $n=18$ schools and $\mathrm{T}=16$ years for 288 observations, and for $\mathrm{PhD}$ and bachelor's degree-granting departments is:

$$
\begin{aligned}
& \text { FACULTY size }_{i t}=\lambda_{1}+\lambda_{2} \text { YEAR }_{t}+\lambda_{3} B A \& S_{i t}+\lambda_{4} M E A N B A \& S_{i}+\lambda_{5} P H D_{i t}+ \\
& \lambda_{6} M \text { ANPHD }_{i}+\lambda_{7} \text { PUBLIC }_{i}+\lambda_{8} M B A_{i}+\varepsilon_{i t}
\end{aligned}
$$

where error term $\varepsilon_{i t}$ is iid across institutions and over time and $\mathrm{E}\left(\varepsilon_{i t}{ }^{2} \mid \mathrm{x}_{\mathrm{it}}\right)=\sigma^{2}$, for $n=24$ schools and $\mathrm{T}=16$ for 384 observations.

Because these models involve no lags on the explanatory degrees, our implied assumption is that the decision makers form a type of rational expectation in that they set the faculty size based on the anticipated number of majors to receive degrees in the future. ${ }^{\mathrm{i}}$ In addition, we have included the mean number of degrees awarded at each institution to reflect a type of historical steady state. That is, the central administration of the institution may have a target number of faculty relative to the long-term expected number of annual graduates from the department that is desired to maintain the department's appropriate role within the institution, but it also is willing to marginally increase or decrease the faculty size based on the near term number of anticipated majors. ${ }^{\text {ii }}$

Estimates reported in Table 2, Panel A, suggest that once the long-term average size of a bachelor's-degree-granting department is taken into account, the marginal effect of an additional economics major is small and insignificant. Faculty size is significantly determined by the institution's desired size (as represented by average number of bachelor degrees), trend and whether it is a public or private institution. A long-term increase of about nine students earning degrees in economics is required to predict one more faculty member is in a department. September 9, 2008: 7 
Moving from a public to a private institution lowers predicted faculty size by nearly four members, ceteris paribus and on average increases the ratio of annual graduates to faculty from 3.6 to 9.0 , an enormous difference. There is a significant steady erosion of faculty size over time; on average a department is predicted to lose a full faculty member every two decades; the decline is about one percent per year, perhaps deemed imperceptible by the colleges. Finally, economics departments in institutions with a business school tend to have significantly larger faculty, ceteris paribus.

At a university with a Ph.D. program in economics (Table 2, Panel B), the marginal effect of an additional undergraduate economics major is statistically significant, but the effect is tiny. Nearly 50 additional bachelor degrees must be anticipated to raise faculty size by one person. There is no effect of changing the anticipated long-term average size of the undergraduate class. It is the average size of the $\mathrm{PhD}$ program that drives faculty size at research universities. Little more than one more $\mathrm{PhD}$ student added to the long-term average is required for predicted faculty size to increase by one, ceteris paribus. There appears to be no secular decline in faculty numbers or any difference between typical faculty size at public and private research universities. The presence of an MBA program is innocuous.

\section{Random Effects Models and Estimates}

There are likely to be substantial school specific effects in the proposed regression models. A natural approach to take in this case is to add "fixed school effects" to the regression by adding institution specific dummy variables to the model. In our case (as often happens in analyzing microeconomic level data) the fixed effects approach is unworkable because other time invariant variables in the model (e.g., PUBLIC in both equations) will be collinear with the 
set of school dummy variables. The alternative approach to incorporating school specific effects is a random effects model. However, the random effects model makes the strong assumption that the error term effects are not correlated with the other explanatory variables in the model. Mundlak's (1978) approach to modeling panel data is a commonly used specification that seeks a middle ground between these two formulations. The Mundlak model posits that the fixed effect in the equation, $\alpha_{\mathrm{i}}$, can be projected upon the group means of the time varying variables, so that

$$
\alpha_{i}=\beta_{1}+\delta^{\prime} \bar{x}_{i}+w_{i}
$$

where $\bar{x}_{i}$ is the set of group (school) means of the time varying variables and $\mathrm{w}_{\mathrm{i}}$ is a (now) random effect that is uncorrelated with the variables and disturbances in the model. Logically, adding the means to the equations picks up the correlation between the school effects and the other variables. Adding the means of the numbers of degrees awarded, as we have already done in the two equations, has the added benefit of enabling us to follow the Mundlak approach to panel data modeling and estimation.

An examination of the school specific residuals from the least squares regressions suggested a considerable amount of heteroscedasticity across schools. We have completed the model by formulating the random effects models for BA and BS degree-granting undergraduate departments as:

$$
\begin{aligned}
& {\text { FACULTY } \text { size }_{i t}=\beta_{1}+\beta_{2} Y E A R_{t}+\beta_{3} B A \& S_{i t}+\beta_{4} M E A N B A \& S_{i}+\beta_{5} P U B L I C_{i}}+ \\
& \beta_{5} B s c h l+\varepsilon_{i t}+u_{i}
\end{aligned}
$$

where error term $\varepsilon$ is iid over time and $\mathrm{E}\left(\varepsilon_{i t}{ }^{2}\right)=\sigma_{\mathrm{i}}{ }^{2}$ for $\mathrm{n}=18$ and $\mathrm{T}_{\mathrm{i}}=16$ and $\mathrm{E}\left[u_{i}^{2}\right]=\theta^{2}$ for $\mathrm{n}=$ 18; and for $\mathrm{PhD}$ and bachelor degree-granting departments as:

September 9, 2008: 9 


$$
\begin{aligned}
& \text { FACULTY } \text { size }_{i t}=\lambda_{1}+\lambda_{2} Y_{E A R_{t}}+\lambda_{3} B A \& S_{i t}+\lambda_{4} M E A N B A \& S_{i}+\lambda_{5} P H D_{i}+ \\
& \lambda_{6} M E A N P H D_{i}+\lambda_{7} P U B L I C_{i}+\lambda_{8} M B A_{i}+\varepsilon_{i t}+u_{i}
\end{aligned}
$$

where error term $\varepsilon_{i t}$ is iid over time with $\mathrm{E}\left[\varepsilon_{i t}{ }^{2}\right]=\sigma_{\mathrm{i}}{ }^{2}$ for $\mathrm{n}=24$ and $\mathrm{T}=16$.

The random effects model is estimated in two steps as usual. At the first step, the variance components are estimated using two sets of linear regression results. First, the deviations from the school means (the equivalent of the school dummy variable regression) removes all the time invariant variables including $\mathrm{u}_{\mathrm{i}}$ from the equation. The school specific sums of squares of these regressions are used to estimate $\sigma_{\mathrm{i}}{ }^{2}$. (The appropriate degrees of freedom correction is not $T-K$ because that would assume that the slopes were estimated separately for each school when they were only estimated once using all schools simultaneously.) We thus use $s_{i}^{2}=1 /(T-K / N) \Sigma_{t} e_{i t, D V}{ }^{2}$. [See Greene (2008, page 204) for discussion of this result.] The variance of $u_{i}$ is then estimated using the simple OLS residuals from the original equation. This is $s_{u}{ }^{2}=(1 / N T-K) \Sigma_{i} \Sigma_{t} e_{i t, O L S^{2}}-(1 / N) \Sigma_{i} s_{i}^{2}$. Finally, the model parameters are estimated using two step feasible generalized least squares, using the results on page 203 in Greene (2008) modified by the school specific variance of $\varepsilon_{i t}$.

The random effects estimates are reported in Table 3. Panel A contains the estimates for those institutions that award only the bachelor's degree in economics. The marginal effect of an additional economics major is again small but now statistically significant. Similarly, the average number of bachelor degrees is significant with a long-term increase of about 11 students earning degrees in economics required to predict that one more faculty member is in a department. Moving from a public to a private institution again lowers predicted faculty size in a large and significant fashion, ceteris paribus, of about 3.5 faculty members, but whether there is September 9, 2008: 10 
or not a business school present is now insignificant. The steady significant decline in faculty size of about one percent per year persists in these estimates.

Panel B, of Table 3, reports the random effects for a university with both an undergraduate and Ph.D. program in economics. The marginal effect of an additional undergraduate economics major is statistically significant, but again small; about 33 more students are needed to justify an additional faculty member. The positive effect of increasing the average size of the undergraduate class is small but significant at the seven percent typical Type I error level. As with the OLS estimates, it is the average size of the $\mathrm{PhD}$ program that drives faculty size. Little more than a single $\mathrm{PhD}$ student added to the long-term average (or target size of the program) is required for predicted faculty size to increase by one, ceteris paribus. In the short run, increasing the number of $\mathrm{PhD}$ degrees, however, has little if any effect. Unlike the OLS estimates, the random effects model reveals a statistically significant secular decline of about one faculty member every 14 years in research universities. Somewhat surprisingly, and in contrast to the findings for baccaleaureate colleges, the results suggest (significant at the 11 percent level, two-tail test) there are about 5.5 more faculty per department in private than in public research universities, ceteris paribus. Consistent with the OLS estimates, the presence of an MBA program appears unrelated to the size of the economics faculty.

\section{Conclusion}

Random effects estimates to predict the number of economics faculty at bachelor's degree level colleges indicate that deans primarily target faculty size to accommodate a specific long-term expected number of students, adding one faculty member for each additional 11 graduating majors. While deans also respond to short term deviations from the long-term September 9, 2008: 11 
average, they are quite cautious. It seems to require over 50 additional unexpected senior majors to provoke the addition of one faculty member.

The process is quite different at research universities that produce both bachelor's and Ph.D. degrees. Faculty size is quite unresponsive to changes in either the long-term average number of graduating economics majors, or short-term deviations from the long-term average. In contrast, faculty size at Ph.D. granting institutions is predicted to increase on a one-for-one basis as the target number of Ph.D.s awarded per year rises.

September 9, 2008: 12 


\section{References}

Ehrlich, Isaac. (2006). “Questions and Answers," University of Buffalo Reporter, 38(1), August 31, 2006. http://www.buffalo.edu/reporter/vol38/vol38n1/columns/qa.html?print=1 (last accessed on $5 / 29 / 2008$ )

Greene, William H. (2008). Econometric Analysis, $6^{\text {th }}$ Ed.. Englewood Cliffs, NJ, Prentice Hall.

Mundlak, Yair (1978). "On the Pooling of Time Series and Cross Section Data," Econometrica. Vol. 46. No. 1 (January): 69-85

Salemi, Michael (1996). "Where Have All the Majors Gone?" Journal of Economic Education. Vol. 27. No. 4 (Fall): 323-325.

Siegfried, John. (2008). “Trends in Undergraduate Economic Degrees 1991-2007," Journal of Economic Education. Vol. 39. No. 3 (Summer): 297-301. 
Table 1: Descriptive Statistics for Departments of Economics in Sample

\begin{tabular}{|c|c|c|c|c|c|}
\hline \multicolumn{6}{|c|}{ Departments of Economics (1991 - 2006) } \\
\hline & \multicolumn{2}{|c|}{ Bachelor Degree Granting } & \multicolumn{3}{|c|}{ Ph.D. Granting } \\
\hline & Faculty & Degrees & Faculty & $B A$ and $B S$ & Ph.D. \\
\hline Mean & 6.61 & 23.78 & 23.20 & 119.92 & 9.58 \\
\hline Standard Dev. & 3.21 & 19.65 & 10.44 & 126.22 & 7.89 \\
\hline Minimum & 2 & 0 & 8 & 2 & 0 \\
\hline \multirow[t]{2}{*}{ Maximum } & 14 & 81 & 56 & 682 & 45 \\
\hline & \multicolumn{2}{|c|}{ Number of Schools } & \multicolumn{3}{|c|}{ Number of Schools } \\
\hline Total & \multicolumn{2}{|c|}{18} & \multicolumn{3}{|c|}{24} \\
\hline Private & \multicolumn{2}{|c|}{4} & \multicolumn{3}{|c|}{15} \\
\hline \multirow[t]{2}{*}{ Public } & \multicolumn{2}{|c|}{14} & \multicolumn{3}{|c|}{9} \\
\hline & \multicolumn{2}{|c|}{$\begin{array}{c}\text { With Business School } \\
7\end{array}$} & \multicolumn{3}{|c|}{$\begin{array}{c}\text { MBA Program Present } \\
3\end{array}$} \\
\hline
\end{tabular}

September 9, 2008: 14 
Table 2. Least Squares Regressions for Faculty Members in Economics Department

Panel A: Bachelor Degree Granting Institutions

Dependent Variable: Faculty

R Squared $\quad 0.6408$

$\mathrm{F} \quad 100.627$

$P(F>100.627) 0.0000$

Observations 288

\begin{tabular}{|l|c|c|c|c|}
\hline & Coefficient & Standard Error & t Statistic & $\mathbf{P}(|\mathbf{t}|>\mathbf{t}$ Stat $)$ \\
\hline Intercept & 10.5405 & 0.5027 & 20.69 & 0.0000 \\
\hline Year & -0.0512 & 0.0248 & -2.06 & 0.0400 \\
\hline Degrees & 0.0189 & 0.0141 & 1.34 & 0.1814 \\
\hline Mean Degrees & 0.1098 & 0.0156 & 7.05 & 0.0000 \\
\hline Public & -4.0549 & 0.2854 & -14.21 & 0.0000 \\
\hline Business School & 0.6610 & 0.2418 & 2.74 & 0.0067 \\
\hline
\end{tabular}

Panel B: Ph.D. Granting Institutions

Dependent Variable: Faculty

R Squared $\quad 0.5460$

F 64.782

$P(F>64.782) \quad 0.0000$

Observations 384

\begin{tabular}{|l|c|c|c|c|}
\hline & Coefficient & Standard Error & t Statistic & $\mathbf{P}(|\mathbf{t}|>\mathbf{t}$ Stat $)$ \\
\hline Intercept & 10.9778 & 1.4383 & 6.63 & 0.0000 \\
\hline Year & -0.0711 & 0.0773 & -0.92 & 0.3587 \\
\hline Ph.D. Degrees & -0.0253 & 0.1018 & -0.25 & 0.8044 \\
\hline BA and BS Degrees & 0.0298 & 0.0105 & 2.84 & 0.0048 \\
\hline Public & 0.7160 & 0.7960 & 0.90 & 0.3690 \\
\hline MBA Program & -0.6549 & 1.1462 & -0.57 & 0.5681 \\
\hline Ph.D. Means & 0.9159 & 0.1155 & 7.93 & 0.0000 \\
\hline BA and BS Means & -0.0064 & 0.0110 & -0.58 & 0.5640 \\
\hline
\end{tabular}

September 9, 2008: 15 
Table 3. Random Effects Regressions for Faculty Members in Economics Department

Panel A: Bachelor Degree Granting Institutions

Dependent Variable: Faculty

R Squared $\quad 0.6194$ (Based on feasible GLS residuals)

Average Institution Specific Variance $\left(\varepsilon_{i t}\right): 0.8187$, Common Variance $\left(u_{i}\right): 2.9386$, Correlation: 0.7821

Observations 18 Institutions, 16 Years

\begin{tabular}{|l|c|c|c|c|}
\hline & Coefficient & Standard Error & t Statistic & $\mathbf{P}(|\mathbf{t}|>\mathbf{t}$ Stat $)$ \\
\hline Intercept & 10.9367 & 1.5139 & 7.22 & 0.0000 \\
\hline Year & -0.0512 & 0.0116 & -4.43 & 0.0000 \\
\hline Degrees & 0.0188 & 0.0066 & 2.84 & 0.0045 \\
\hline Mean Degrees & 0.0827 & 0.0297 & 2.78 & 0.0054 \\
\hline Public & -3.6326 & 0.9710 & -3.74 & 0.0002 \\
\hline Business School & 0.8066 & 0.8893 & 0.91 & 0.3643 \\
\hline
\end{tabular}

\section{Panel B: Ph.D. Granting Institutions}

Dependent Variable: Faculty

R Squared $\quad 0.54800$ (Based on feasible GLS residuals)

Average Institution Specific Variance $\left(\varepsilon_{i t}\right): 6.6870$, Common Variance $\left(u_{i}\right): 41.2825$, Correlation: 0.8606 Observations 24 Institutions, 16 years

\begin{tabular}{|l|c|c|c|c|}
\hline & Coefficient & Standard Error & t Statistic & $\mathbf{P}(|\mathbf{t}|>\mathbf{t}$ Stat $)$ \\
\hline Intercept & 8.2130 & 6.5932 & 1.25 & 0.2129 \\
\hline Year & -0.0711 & 0.0289 & -2.46 & 0.0138 \\
\hline Ph.D. Degrees & -0.0252 & 0.0380 & -0.66 & 0.5068 \\
\hline BA and BS Degrees & 0.0298 & 0.0039 & 7.60 & 0.0000 \\
\hline Public & 5.5648 & 3.3948 & 1.64 & 0.1012 \\
\hline MBA Program & 1.6974 & 4.2882 & 0.40 & 0.6922 \\
\hline Ph.D. Means & 0.9786 & 0.1877 & 5.22 & 0.0000 \\
\hline BA and BS Means & -0.0212 & 0.0144 & -1.48 & 0.1391 \\
\hline
\end{tabular}

September 9, 2008: 16 
'An alternative assumption would call for the determination of faculty size at time $t$ based on lagged degrees: $t-1, t-2$ or $t-3$, reflecting more precisely the timing of the teaching responsibilities associated with graduating students. We experimented with one, two and three year lags with no material difference to the results reported in Table 2 but with the loss of one year of observations for each lag, and so abandoned the lagged degrees model.

ii One of us, as a member on an external review team for a well known economics department, was told by a high ranking central administrator that the department had gotten all the additional lines it was going to get because it now had too many majors for the good of the institution. Historically, the institution was known for turning out engineers and the economics department was attracting too many from engineering. 